\title{
Infections in Transplantation: Introduction and Overview
}

\author{
Amar Safdar
}

Transplantation remains a pioneering scientific innovation that has a significant impact on restoring well-being for patients and benefit society as a whole. Blood and marrow hematopoietic stem cells have become accepted and, in some instances, established approach to treat incurable neoplastic diseases and congenital disorders of immune system [1]. Similarly, use of allografts in patients with end-stage organ disease involving the liver, kidneys, intestines, heart, and lungs has provided a possibility for continuation of life and a potential for patients to integrate and resume participation in their communities [2]. Recent advances in limb, integument, and face transplantation underscore the substantial leap forward in restoring normalcy for individuals with devastating and often catastrophic physical encumbrance $[3,4]$.

In patients undergoing solid organ transplantation, advancement in understanding the complex interplay within various facets of immune response against the transplanted allogeneic tissue that recipients' immune system fails to recognize as "self" has resulted in encouraging long-term outcomes [5]. These achievements in decoding higher mammalian immunity underscore the recent progress made in development and implementation of refined strategies to harness potentially devastating immune rejection of the implanted solid organ allograft [6]. The antirejection strategies, as expected, involve a delicate balance that favors preservation of a functioning allograft and aims at limit severity of drug-induced suppression of recipients' immune function, which is crucial for the surveillance against various neoplastic processes; conventional and opportunistic infections.

\footnotetext{
A. Safdar $(\bowtie)$

Clinical Associate Professor of Medicine, Texas Tech University Health Sciences Center El Paso, Paul L. Foster School of

Medicine, El Paso, TX, USA

e-mail: amar.safdar@cidimmunology.com
}

A similar, albeit an opposing role of undesired immune response comes into play in patients undergoing hematopoietic blood and marrow stem cell transplantation from a foreign donor. The conflict arises from aforementioned disconnect between immune recognition of self versus nonself $[7,8]$. These transplanted stem cells install foreign effector immune cells in the recipient, and if remain unabated, the resulting graft-versus-host disease is capable of unleashing potentially ruinous systemic inflammation resulting in irreversible tissue damage and death [7]. The stem cell graft restores immunity and functional marrow in patients in need for myeloablative antineoplastic therapy. Furthermore, it is the foreign, graft-mediated, adaptive cancer immune surveillance that has now been widely recognized as the pivotal feature that sustains cancer in remission following successful allogeneic hematopoietic stem cell transplantation. This feature of stem cell graft-assisted antitumor response is recognized as "graftversus-leukemia or graft-versus-tumor effect." Donorderived adaptive antitumor immunity is an important objective of allogeneic stem cell transplantation, especially in patients with hematologic malignancies, and forms the bases for donor lymphocyte infusions to treat cancer recurrences during posttransplant period [9]. As in patients following solid organ transplants, in recipients of allogeneic HSCT, anti-GVHD therapy is assessed and continuously refined to achieve the lowest possible cumulative iatrogenic immune suppression required to prevent or treat GVHD, whereas an earnest attempt is made for preservation of recipients' immune function such that the risk of conventional and opportunistic infections and malignancies do not overwhelm the projected efficacy and feasibility of these lifesaving procedures.

A number of agents have been successfully used for prevention and treatment of graft-versus-host disease and solid organ allograft rejection $[8,10]$. Severity of immune dysfunction is in most instance a direct consequence of treatment with these agents that are commonly prescribed 
as combination drug regimens. Cyclosporine was the first major breakthrough in this regard; subsequent generation calcineurin inhibitors (CNI) have improved therapeutic index although resultant severe immune suppression and the risk for opportunistic infection like CMV, BK virus, and certain posttransplant cancers question the therapeutic feasibility for agents such as tacrolimus, especially in patients with low risk for allograft-related complications. Serious infections due to cytomegalovirus including viremia and end-organ disease, BK virus viremia, viruria, and BK virus allograft nephropathy with risk for potential graft compromise, rare progressive multifocal leukoencephalopathy due to polyomavirus, higher potential for opportunist cancers such as Kaposi's sarcoma, EBV lymphoproliferative disorders among others, are well-recognized limitations in individuals given tacrolimus for extended duration with doses leading to prolong high serum drug concentration [11]. Experience with sirolimus, a macrolide xenobiotic that induces potent immune suppression via inhibition of mechanistic target of rapamycin (mTOR; a conserved threonine and serine protein kinase) was associated with lower incidence of CMV infection in solid organ transplant recipients. This protective antiviral effect of mTOR inhibitors against BK virus nephropathy after renal transplantation has not been noted consistently. Additionally, antitumor properties of mTOR inhibitors may favorably influence the lower incidence and risk for posttransplant malignancies in recipients of solid organ allografts, especially those with a profile that indicates low risk for graft rejection [12].

Monoclonal antibodies against T- and B-cell pathways have also gained prominence, as potential treatment options. Alemtuzumab (Campath) is a monoclonal antibody that targets C52 antigen expressed on all lymphocytes. Treatment with Campath results in profound lymphocyte depletion. The drug-induced immune suppression may last for up to 9 months, although maximum degree of lymphopenia is noted between 8 and 9 weeks after therapy. As part of HSCT preparatory condition regimen, treatment with alemtuzumab was associated with reduced risk for GVHD following allogeneic hematopoietic stem cell transplantation [13].

In kidney transplant recipients, the risk for organ rejection was low in patients given alemtuzumab; however, this benefit was mainly observed in patients that were at a low risk for allograft rejection [14]. Other trials are underway with the aim to explore regimen(s) that may spare CNI (tacrolimus) for the prevention of allograft rejection.

Humanized monoclonal antibody rituximab that targets CD20 antigen expressed prominently and selectively on B lymphocytes forms the cornerstone for treatment of solid organ antibody-mediated renal allograft rejection. It is also considered the standard of care for the treatment of posttransplant B-cell lymphoproliferative disorders [15].

Systemic glucocorticoids have maintained relevance in drug cocktails given to prevent and treat solid organ graft rejection and GVHD. Since the early observation enabled addition of corticosteroids to successfully reduce cyclosporine dose that was traditionally needed to prevent rejection of transplanted allograft, this observation was regarded as a major breakthrough and forged the path for preservation of transplanted organs without serious, lifethreatening CNI toxicity. Detailed discussion regarding immunosuppressive agents for prevention and treatment of allograft rejection is provided in chapters throughout this book.

A keen understanding of patients' underlying immune $\operatorname{defect}(\mathrm{s})$ is the knowledge cornerstone, essential for optimizing infection risk stratification, assessing need for preventive, preemptive or empiric antimicrobial therapy. This information serves as an imperative in establishing meaningful patient-centered management and infection prevention paradigm [16, 17]. Table 1.1 provides an outline for such a relationship between underlying immune defects and susceptibility for particular group of pathogens. It is also important to note that a combination of unrelated immune defects may overlap. Furthermore, such patients may present with multiple infections concurrently, sequentially, or in close proximity to a primary infection episode, with a variety of conventional and opportunistic microorganisms.

An extensive exposure to hospital environment poses risk for transplant recipients to acquire infections that may not respond to conventional antimicrobial drugs. The recent interest in exploring the potential influence of perturbation and reorganization of hosts' microbial flora or microbiota resulting from extensive exposure to healthcare environment, broad-spectrum antimicrobial drugs among other factors, has yielded greater insight into a field that was largely underappreciated for decades. Altered orointestinal microbiota has been proposed in limited observational studies to influence the risk for acquiring infection, recurrence of previously resolved infection, suboptimum response to antimicrobial therapy, and importantly, long-term viability of the transplanted allograft [18-20]. The possibility of noninfectious complications and their potential relationship with altered hosts' microbiota are currently under investigation.

An important approach in the assessment of transplant patients lends from the understanding and knowledge of temporal relationship for the risk of infection that may occur during various clinical phases after transplantation procedure (Table 1.2, with Figs. 1.1, 1.2, 1.3, 1.4, 1.5, and 1.6). For example, patients with long-standing chronic GVHD are 
Table 1.1 Infections in transplant patients in relationship with the underlying immune defects

\begin{tabular}{|c|c|c|c|c|c|}
\hline Immune defect & Bacteria & $\begin{array}{l}\text { Yeasts and dimorphic } \\
\text { fungi }\end{array}$ & Filamentous molds & Viruses & Parasites \\
\hline Granulocytopenia & Staphylococcus aureus & Candida spp. & $\begin{array}{l}\text { Hyalohyphomycetes } \\
\text { (hyaline or clear wall) }\end{array}$ & $\begin{array}{l}\text { Herpes simplex virus } \\
\text { type I and II }\end{array}$ & \\
\hline \multirow[t]{18}{*}[\mathrm{ANC}<500\mathrm{cell}/\mathrm{ml}]{} & $\begin{array}{l}\text { Streptococcus } \\
\text { pneumoniae }\end{array}$ & Candida albicans $\mathrm{s}^{\mathrm{a}}$ & Aspergillus fumigatus & Varicella zoster virus & \\
\hline & $\begin{array}{l}\text { Streptococcus gp A, } \\
\text { and gp B }\end{array}$ & $\begin{array}{l}\text { Non-albicans } \\
\text { Candida spp. }\end{array}$ & Aspergillus flavus & & \\
\hline & $\begin{array}{l}\text { Enterococci including } \\
\text { VRE }^{\text {b }}\end{array}$ & Candida glabrata & Aspergillus niger & & \\
\hline & $\begin{array}{l}\text { Coagulase-negative } \\
\text { Staphylococcus }{ }^{\mathrm{d}}\end{array}$ & Candida krusei $^{\mathrm{e}}$ & Aspergillus terreus ${ }^{\mathrm{f}}$ & & \\
\hline & Enterobacteriaceae & $\begin{array}{l}\text { Candida } \\
\text { parapsilosis }^{\mathrm{g}}\end{array}$ & Aspergillus nidulans & & \\
\hline & Escherichia coli & $\begin{array}{l}\text { Candida } \\
\text { guilliermondii }{ }^{\mathrm{g}}\end{array}$ & $\begin{array}{l}\text { Non-Aspergillus } \\
\text { hyalohyphomycetes }\end{array}$ & & \\
\hline & Klebsiella species & Non-Candida yeasts ${ }^{\mathrm{h}}$ & Fusarium spp. ${ }^{\mathrm{i}}$ & & \\
\hline & Enterobacter spp. & Trichosporon asahii & Paecilomyces & & \\
\hline & Proteus spp. & $\begin{array}{l}\text { Saprochaete } \\
\text { capitata }^{j}\end{array}$ & Mucormycoses & & \\
\hline & Citrobacter spp. & Saccharomyces & Mucorales species ${ }^{\mathrm{k}}$ & & \\
\hline & Serratia spp. & $\begin{array}{l}\text { Magnusiomyces } \\
\text { capitatus }\end{array}$ & $\begin{array}{l}\text { Dematiaceous (black or } \\
\text { melanin pigmented) } \\
\text { molds }\end{array}$ & & \\
\hline & $\begin{array}{l}\text { Nonfermentative } \\
\text { gram-negative bacteria }\end{array}$ & $\begin{array}{l}\text { Rhodotorula } \\
\text { mucilaginosa }\end{array}$ & $\begin{array}{l}\text { Alternaria, Bipolaris, } \\
\text { spp. }\end{array}$ & Curvularia, Exserohilum & \\
\hline & $\begin{array}{l}\text { Pseudomonas } \\
\text { aeruginosa }\end{array}$ & $\begin{array}{l}\text { Wickerhamomyces } \\
\text { anomalus }\end{array}$ & $\begin{array}{l}\text { Pseudallescheria } \\
\text { boydii }\end{array}$ & & \\
\hline & $\begin{array}{l}\text { Stenotrophomonas } \\
\text { maltophilia }\end{array}$ & Pichia kudriavzevii & $\begin{array}{l}\text { Scedosporium } \\
\text { apiospermum }\end{array}$ & & \\
\hline & $\begin{array}{l}\text { Acinetobacter } \\
\text { species }\end{array}$ & $\begin{array}{l}\text { Cyberlindnera } \\
\text { fabianii }\end{array}$ & $\begin{array}{l}\text { Scedosporium } \\
\text { prolificans }\end{array}$ & & \\
\hline & Achromobacter spp. & Kodamaea ohmeri & & & \\
\hline & & $\begin{array}{l}\text { Lodderomyces } \\
\text { elongisporus }\end{array}$ & & & \\
\hline & & Pseudozyma & & & \\
\hline \multirow[t]{14}{*}{$\begin{array}{l}\text { Cellular immune } \\
\text { defects }\end{array}$} & $\begin{array}{l}\text { Nocardia asteroides } \\
\text { complex }\end{array}$ & $\begin{array}{l}\text { Cryptococcus } \\
\text { neoformans }\end{array}$ & Aspergillus spp. & $\begin{array}{l}\text { Human } \\
\text { cytomegalovirus }\end{array}$ & $\begin{array}{l}\text { Toxoplasma } \\
\text { gondii }\end{array}$ \\
\hline & $\begin{array}{l}\text { Salmonella } \\
\text { typhimurium }\end{array}$ & Endemic mycoses & $\begin{array}{l}\text { Non-Aspergillus } \\
\text { hyalohyphomycetes }\end{array}$ & Respiratory viruses & $\begin{array}{l}\text { Strongyloides } \\
\text { stercoralis }^{1}\end{array}$ \\
\hline & Salmonella enteritidis & $\begin{array}{l}\text { Histoplasma } \\
\text { capsulatum }\end{array}$ & Pneumocystis jirovecii & $\begin{array}{l}\text { Influenza A and } \\
\text { influenza B }\end{array}$ & $\begin{array}{l}\text { Microsporidium } \\
\text { spp. }\end{array}$ \\
\hline & Rhodococcus equi & $\begin{array}{l}\text { Coccidioides } \\
\text { immitis }\end{array}$ & $\begin{array}{l}\text { Dematiaceous (black } \\
\text { pigmented wall) molds }\end{array}$ & $\begin{array}{l}\text { Respiratory syncytial } \\
\text { virus }\end{array}$ & Cryptosporidium \\
\hline & $\begin{array}{l}\text { Rhodococcus } \\
\text { bronchialis }\end{array}$ & $\begin{array}{l}\text { Blastomyces } \\
\text { dermatitidis }\end{array}$ & Mucormycoses & Parainfluenza type-3 & Microspora spp. \\
\hline & Listeria monocytogenes & $\begin{array}{l}\text { Paracoccidioides } \\
\text { brasiliensis }\end{array}$ & $\begin{array}{l}\text { Cryptococcus } \\
\text { neoformans }\end{array}$ & Adenovirus & Cyclospora spp. \\
\hline & $\begin{array}{l}\text { Mycobacterium } \\
\text { tuberculosis }\end{array}$ & & Endemic mycoses & $\begin{array}{l}\text { Human coronavirus } \\
\text { HKU1, NL63, OC43 } \\
\text { and C229E }\end{array}$ & $\begin{array}{l}\text { Leishmania } \\
\text { donovani }^{\mathrm{n}}\end{array}$ \\
\hline & $\begin{array}{l}\text { Nontuberculous } \\
\text { mycobacteria }\end{array}$ & & $\begin{array}{l}\text { Histoplasma } \\
\text { capsulatum }\end{array}$ & $\begin{array}{l}\text { Corona virus, SARS, } \\
\text { MERS }^{\circ}\end{array}$ & $\begin{array}{l}\text { Leishmania } \\
\text { infantum }^{\mathrm{p}}\end{array}$ \\
\hline & Legionella spp. & & Coccidioides immitis & $\begin{array}{l}\text { Human } \\
\text { metapneumovirus }{ }^{q}\end{array}$ & \\
\hline & Yersinia spp. & & $\begin{array}{l}\text { Blastomyces } \\
\text { dermatitidis }\end{array}$ & Varicella & \\
\hline & Campylobacter jejuni ${ }^{\mathrm{r}}$ & & $\begin{array}{l}\text { Paracoccidioides } \\
\text { brasiliensis }\end{array}$ & Varicella zoster virus & \\
\hline & & & & Human herpes virus 6 & \\
\hline & & & & Parvovirus B19 & \\
\hline & & & & Hantavirus & \\
\hline
\end{tabular}


Table 1.1 (continued)

\begin{tabular}{|c|c|c|c|c|c|}
\hline Immune defect & Bacteria & $\begin{array}{l}\text { Yeasts and dimorphic } \\
\text { fungi }\end{array}$ & Filamentous molds & Viruses & Parasites \\
\hline \multirow{5}{*}{$\begin{array}{l}\text { Humoral immune } \\
\text { defects }\end{array}$} & Encapsulated bacteria & & & Varicella zoster virus $^{\mathrm{s}}$ & Giardia lamblia \\
\hline & $\begin{array}{l}\text { Streptococcus } \\
\text { pneumoniae }\end{array}$ & & & $\begin{array}{l}\text { Echovirus and other } \\
\text { enteroviruses }\end{array}$ & Babesia microti \\
\hline & $\begin{array}{l}\text { Haemophilus } \\
\text { influenzae }\end{array}$ & & & & \\
\hline & $\begin{array}{l}\text { Neisseria } \\
\text { meningitidis }\end{array}$ & & & & \\
\hline & Campylobacter jejuni & & & & \\
\hline \multirow{5}{*}{$\begin{array}{l}\text { Splenectomy and } \\
\text { functional } \\
\text { hyposplenism }\end{array}$} & Encapsulated bacteria & & & & Giardia lamblia \\
\hline & $\begin{array}{l}\text { Streptococcus } \\
\text { pneumoniae }\end{array}$ & & & & Babesia microti \\
\hline & $\begin{array}{l}\text { Haemophilus } \\
\text { influenzae }\end{array}$ & & & & \\
\hline & $\begin{array}{l}\text { Neisseria } \\
\text { meningitidis }\end{array}$ & & & & \\
\hline & $\begin{array}{l}\text { Capnocytophaga } \\
\text { canimorsus }\end{array}$ & & & & \\
\hline \multirow[t]{12}{*}{$\begin{array}{l}\text { Mixed immune } \\
\text { defects }\end{array}$} & $\begin{array}{l}\text { Streptococcus } \\
\text { pneumoniae }\end{array}$ & & Pneumocystis jirovecii & Respiratory viruses & $\begin{array}{l}\text { Toxoplasma } \\
\text { gondii }\end{array}$ \\
\hline & Staphylococcus aureus & & Aspergillus spp. & Adenovirus & $\begin{array}{l}\text { Strongyloides } \\
\text { stercoralis }\end{array}$ \\
\hline & $\begin{array}{l}\text { Haemophilus } \\
\text { influenzae }\end{array}$ & & Candida spp. & Varicella zoster virus & \\
\hline & Klebsiella pneumonia & & $\begin{array}{l}\text { Cryptococcus } \\
\text { neoformans }\end{array}$ & & \\
\hline & $\begin{array}{l}\text { Pseudomonas } \\
\text { aeruginosa }\end{array}$ & & Mucormycoses & & \\
\hline & Acinetobacter spp. & & Endemic mycoses & & \\
\hline & Enterobacter spp. & & $\begin{array}{l}\text { Dematiaceous (black) } \\
\text { molds }\end{array}$ & & \\
\hline & $\begin{array}{l}\text { Stenotrophomonas } \\
\text { maltophilia }\end{array}$ & & & & \\
\hline & $\begin{array}{l}\text { Nocardia asteroides } \\
\text { complex }\end{array}$ & & & & \\
\hline & Listeria monocytogenes & & & & \\
\hline & Legionella spp. & & & & \\
\hline & Campylobacter jejuni & & & & \\
\hline
\end{tabular}

Patients with mixed immune defects include recipients of allogeneic hematopoietic stem cell transplant; patients receiving treatment for acute or chronic graft-versus-host disease; acute or chronic solid organ allograft rejection

Abbreviations: VRE vancomycin-resistant enterococci, SARS severe acute respiratory syndrome, MERS Middle East respiratory syndrome

an the past two decades, the prevalence of non-albicans invasive candidiasis is seen in excess of Candida albicans infections; the emergence of invasive disease due to Candida auris with limited susceptibility to currently used antifungal drugs is a challenge

${ }^{b}$ Certain transplant units across the USA have seen a high level of VRE colonization and subsequent risk for invasive disease; these infections are often a surrogate and reflect hosts' high-risk status

'Increasing reports of echinocandin resistance among clinical isolates of C. glabrata is an alarming trend, where this to become more prominent in the future

${ }^{\mathrm{d}}$ Among CoNS group of bacteria, an emerging and recently described highly virulent Staphylococcus lugdunensis causes tissue-destructive infections similar to $S$. aureus with an emphasis on necrotizing and difficult-to-treat endocarditis

${ }^{\mathrm{e}}$ Candida krusei is intrinsically nonsusceptible to fluconazole and to some extent itraconazole; these yeasts are uniformly susceptible to the broadspectrum triazoles such as voriconazole, posaconazole, and isavuconazonium sulfate

${ }^{\mathrm{f}}$ Aspergillus terreus is the only clinically relevant Aspergillus species that exhibit variable degree of resistance to amphotericin $\mathrm{B}$, thereby increasing the probability of failure to amphotericin-based therapy

${ }^{g}$ Candida parapsilosis and $C$. guilliermondii have demonstrated less inherent in vitro susceptibility to the echinocandins; alternative antifungal agents are suggested to treat such infections

${ }^{\mathrm{h} N o n-C a n d i d a}$ and non-Cryptococcal yeasts are rare cause of fungemia seen mainly in patients with severe immune dysfunction and those with chronic lung disease

${ }^{\mathrm{i}}$ Fusarium spp. infections are now increasingly attributed to food-related intestinal tract colonization and invasive disease during periods of severe immune suppression, such as profound and prolonged neutropenia, especially in patients with extensive orointestinal mucosal disruption; other filamentous fungal pathogens from food are Aspergillus and Mucor spp. Rare organisms linked to food and food products include Lichtheimia, Curvularia, Phoma, Trichoderma, Alternaria, Acremonium, Paecilomyces, Penicillium, Achaetomium, Amesia, Botryotrichum, Chaetomium, Dichotomopilus; Microascus, Scopulariopsis, and Wallemia. Mucor circinelloides was isolated from yogurt samples and presumed to cause illness in $>200$ consumers 
Table 1.1 (continued)

${ }^{\mathrm{j}}$ Geotrichum capitatum is now named Saprochaete capitata

${ }^{\mathrm{k}}$ Mucormycoses in transplant recipients remain an uncommon cause of invasive fungal disease, although patients with voriconazole breakthrough mold disease have significantly higher probability of mucormycosis

${ }^{1}$ Strongyloides stercoralis may lead to serious, life-threatening hyperinfection syndrome in patients with marked cellular immune defects following allogeneic allograft transplantation, albeit, this remains a rare complication in patients undergoing transplantation even in the endemic regions

mThese strains of human coronavirus may cause potentially serious lower respiratory tract disease in the immunocompromised host

${ }^{\mathrm{n}} L$. donovani and $L$. infantum may lead to serious visceral leishmaniasis in patients with profound cellular immune defects; $L$. donovani is seen in Africa and Asia

${ }^{\circ}$ These novel outbreak stains of coronavirus have been observed to cause serious illness in immunosuppressed patients and those with diabetes mellitus, ischemic heart disease, or end-stage kidney disease

${ }^{\mathrm{P}}$ L. infantum is seen in Africa, Europe, Mediterranean, Central and South America

${ }^{\mathrm{T}}$ Systemic extrapulmonary infection including viral encephalitis along with viral pneumonitis in allogeneic stem cell transplant recipients has been noted to cause devastating and life-threatening illness

rThe incidence of campylobacter disease in AIDS patients is 40-fold higher than in the general population; patients with humoral and cellular immune defects are considered susceptible; it is important to recognize the serious sequelae such as Guillain-Barre syndrome, and reactive arthritis may follow acute infection episode in a small group of patients

${ }^{\mathrm{s}} \mathrm{VZV}$ is rarely associated with systemic dissemination in patients with humoral immune defects or even those with mixed immune dysfunctions

Table 1.2 Infections in recipients of allogeneic hematopoietic stem cell transplantation

\begin{tabular}{|c|c|c|c|c|c|}
\hline Pathogens & $\begin{array}{l}\text { Pretransplant disease or } \\
\text { high-risk exposure-related } \\
\text { infections }\end{array}$ & $\begin{array}{l}\text { Pre-engraftment during } \\
\text { neutropenia ( } 0-30 \text { days) }\end{array}$ & $\begin{array}{l}\text { Post-engraftment } \\
\text { including acute GVHD } \\
\text { (30-100 days) }\end{array}$ & $\begin{array}{l}\text { Posttransplant } \\
\text { including chronic } \\
\text { GVHD (>100 days) }\end{array}$ & $\begin{array}{l}\text { Posttransplant } \\
\text { seasonal } \\
\text { community-onset } \\
\text { infections }\end{array}$ \\
\hline \multirow[t]{10}{*}{ Bacteria } & Streptococcus pneumoniae ${ }^{\mathrm{a}}$ & Staphylococcus aureus ${ }^{\mathrm{b}}$ & $\begin{array}{l}\text { GPB and GNB } \\
\text { bacteremia }^{c}\end{array}$ & Encapsulated bacteria $^{\mathrm{d}}$ & $\begin{array}{l}\text { Community } \\
\text { acquired } \\
\text { pneumonia }\end{array}$ \\
\hline & Staphylococcus aureus ${ }^{\mathrm{b}}$ & $\begin{array}{l}\text { Coagulase-negative } \\
\text { staphylococcus }^{\mathrm{e}}\end{array}$ & $\begin{array}{l}\text { Listeria } \\
\text { monocytogenes }{ }^{\mathrm{f}}\end{array}$ & $\begin{array}{l}\text { GPB and GNB } \\
\text { bacteremia }^{c}\end{array}$ & $\begin{array}{l}\text { Community onset } \\
\text { sinusitis }\end{array}$ \\
\hline & $\begin{array}{l}\text { Coagulase-negative } \\
\text { staphylococcus }^{\mathrm{e}}\end{array}$ & Enterobacteriaceae $e^{\mathrm{g}}$ & Nocardiosis $^{\mathrm{h}}$ & $\begin{array}{l}\text { Listeria } \\
\text { monocytogenes }\end{array}$ & $\begin{array}{l}\text { Community onset } \\
\text { or travel-related } \\
\text { enterocolits }\end{array}$ \\
\hline & Enterobacteriaceae & Escherichia coli & & Nocardiosis & $\begin{array}{l}\text { Community onset } \\
\text { urinary tract } \\
\text { infection including } \\
\text { pyelonephritis }\end{array}$ \\
\hline & Escherichia coli & $\begin{array}{l}\text { Klebsiella pneumoniae } \\
\text { and Klebsiella oxytoca }\end{array}$ & & & $\begin{array}{l}\text { Community } \\
\text { onset Clostridium } \\
\text { difficile-associated } \\
\text { diarrhea }\end{array}$ \\
\hline & $\begin{array}{l}\text { Klebsiella pneumoniae } \\
\text { and Klebsiella oxytoca }\end{array}$ & $\begin{array}{l}\text { Nonfermentative } \\
\text { gram-negatives }{ }^{i}\end{array}$ & & & \\
\hline & $\begin{array}{l}\text { Nonfermentative } \\
\text { gram-negatives }{ }^{i}\end{array}$ & $\begin{array}{l}\text { Pseudomonas } \\
\text { aeruginosa }\end{array}$ & & & \\
\hline & $\begin{array}{l}\text { Pseudomonas } \\
\text { aeruginosa }\end{array}$ & $\begin{array}{l}\text { Stenotrophomonas } \\
\text { maltophilia }\end{array}$ & & & \\
\hline & $\begin{array}{l}\text { Stenotrophomonas } \\
\text { maltophilia }\end{array}$ & $\begin{array}{l}\text { Clostridium difficile- } \\
\text { associated diarrhea }^{j}\end{array}$ & & & \\
\hline & $\begin{array}{l}\text { Clostridium difficile- } \\
\text { associated diarrhea }^{j}\end{array}$ & & & & \\
\hline \multirow[t]{5}{*}{ Mycobacteria } & M. tuberculosis ${ }^{\mathrm{k}}$ & & & $\begin{array}{l}\text { Reactivation of latent } \\
\text { tuberculosis }\end{array}$ & \\
\hline & M. kansasii ${ }^{1}$ & & & $\begin{array}{l}\text { Relapse of previously } \\
\text { treated } M \text {. kansasii } \\
\text { infection }\end{array}$ & \\
\hline & $\begin{array}{l}\text { Nontuberculous } \\
\text { mycobacteria }\end{array}$ & & & $\begin{array}{l}\text { New or relapse MAC } \\
\text { infection }^{\mathrm{m}}\end{array}$ & \\
\hline & $\begin{array}{l}\text { Rapid-growing } \\
\text { mycobacteria }\end{array}$ & & & & \\
\hline & $\begin{array}{l}\text { Slow-growing } \\
\text { mycobacteria }\end{array}$ & & & & \\
\hline
\end{tabular}


Table 1.2 (continued)

\begin{tabular}{|c|c|c|c|c|c|}
\hline Pathogens & $\begin{array}{l}\text { Pretransplant disease or } \\
\text { high-risk exposure-related } \\
\text { infections }\end{array}$ & $\begin{array}{l}\text { Pre-engraftment during } \\
\text { neutropenia ( } 0-30 \text { days) }\end{array}$ & $\begin{array}{l}\text { Post-engraftment } \\
\text { including acute GVHD } \\
\text { (30-100 days) }\end{array}$ & $\begin{array}{l}\text { Posttransplant } \\
\text { including chronic } \\
\text { GVHD (>100 days) }\end{array}$ & $\begin{array}{l}\text { Posttransplant } \\
\text { seasonal } \\
\text { community-onset } \\
\text { infections }\end{array}$ \\
\hline \multirow[t]{7}{*}{ Viruses } & $\begin{array}{l}\text { Herpes simplex type } 1 \text { and } \\
\text { II }\end{array}$ & $\begin{array}{l}\text { Herpes simplex type I } \\
\text { and II }\end{array}$ & Cytomegalovirus $^{\mathrm{n}}$ & Cytomegalovirus $^{\circ}$ & Influenza $\mathrm{A}$ and $\mathrm{B}^{\mathrm{p}}$ \\
\hline & Human cytomegalovirus ${ }^{q}$ & Varicella zoster virus $^{\mathrm{r}}$ & Human herpesvirus ${ }^{\mathrm{s}}$ & Human herpesvirus $6^{\mathrm{s}}$ & Parainfluenza \\
\hline & Varicella zoster virus & Cytomegalovirus $^{\mathrm{t}}$ & Adenovirus $^{\mathrm{u}}$ & Adenovirus $^{\mathrm{u}}$ & $\mathrm{RSV}^{\mathrm{v}}$ \\
\hline & & Human herpesvirus $6^{\mathrm{s}}$ & BK virus cystitis ${ }^{w}$ & $\begin{array}{l}\text { Epstein-Barr virus } \\
\text { PTLD }^{x}\end{array}$ & hMPV ${ }^{y}$ \\
\hline & & Adenovirus $^{\mathrm{u}}$ & $\begin{array}{l}\text { Epstein-Barr virus } \\
\text { PTLD }^{x}\end{array}$ & Parvovirus B $19^{\mathrm{z}}$ & $\mathrm{hCoV}^{\mathrm{aa}}$ \\
\hline & & & & BK virus cystitis ${ }^{w}$ & \\
\hline & & & & JC virus PML ${ }^{a b}$ & \\
\hline \multirow{7}{*}{$\begin{array}{l}\text { Molds and } \\
\text { yeasts }\end{array}$} & Invasive aspergillosis & Candida fungemia ${ }^{\text {ac }}$ & Invasive aspergillosis ${ }^{\text {ad }}$ & Invasive aspergillosis ${ }^{\text {ae }}$ & \\
\hline & Endemic mycosis & $\begin{array}{l}\text { Invasive aspergillosis and } \\
\text { rare molds }{ }^{\text {af }}\end{array}$ & Invasive candidiasis ${ }^{\mathrm{ag}}$ & Invasive candidiasis ${ }^{\text {ah }}$ & \\
\hline & Cryptococcal disease & & Pneumocystis jirovecii ${ }^{\mathrm{ai}}$ & Pneumocystis jirovecii & \\
\hline & Invasive candidiasis & & Zygomycosis $^{\text {aj }}$ & Zygomycosis ${ }^{\text {aj }}$ & \\
\hline & & & Fusariosis $^{\mathrm{ak}}$ & Fusariosis ${ }^{\mathrm{ak}}$ & \\
\hline & & & $\begin{array}{l}\text { Dematiaceous (melanin } \\
\text { pigmented) molds }\end{array}$ & $\begin{array}{l}\text { Dematiaceous } \\
\text { (melanin pigmented) } \\
\text { molds }^{\text {al }}\end{array}$ & \\
\hline & & & Cryptococcal disease $\mathrm{am}^{\mathrm{am}}$ & Cryptococcal disease ${ }^{a m}$ & \\
\hline \multirow[t]{4}{*}{ Parasites } & Toxoplasma gondii & & Toxoplasma gondii $^{\text {an }}$ & Toxoplasma gondii ${ }^{\text {an }}$ & \\
\hline & Strongyloidiasis ${ }^{\mathrm{ao}}$ & & Strongyloidiasis $^{\text {ap }}$ & Strongyloidiasis $^{\mathrm{ap}}$ & \\
\hline & Chagas disease $^{\mathrm{aq}}$ & & Chagas disease & Chagas disease & \\
\hline & Leishmaniasis $^{\text {ar }}$ & & Leishmaniasis & Leishmaniasis & \\
\hline
\end{tabular}

aPneumococcus is the leading cause of community-onset bacterial pneumonia, and patients with hematologic malignancies, especially those with cancer or antineoplastic therapy-related humoral immune dysfunction and various other medical comorbid conditions such as diabetes mellitus, chronic structural lung diseases like emphysema, end-stage kidney disease, and cirrhosis of liver to name a few, are at risk for potentially severe systemic disease

${ }^{\mathrm{b}}$ The emergence and global spread of community-acquired methicillin-resistant $S$. aureus has made empiric use of anti-staphylococcal penicillin's obsolete

${ }^{\mathrm{c} C}$ Catheter-related bloodstream infection, extensive healthcare environment exposure and hospital-acquired pathogens, persistent mucositis, orointestinal or cutaneous hyper-acute and acute GVHD, and accelerated iatrogenic immune suppression including need for high-dose corticosteroids are salient factors that promote invasive bacterial infections during this period. Pretransplant colonization due to VRE, MRSA, or MDR GNB including MRD Pseudomonas, ESBL-producing Enterobacteriaceae, and some food-borne fungi such as Fusarium spp., especially in transplant unit located in certain geographic areas, are thought to promote infections due to these pathogens

${ }^{\mathrm{d}}$ Hyposplenism after HSCT is a late complication and commonly attributed to late-onset acute GVHD, most frequently noted in patients with chronic GVHD. It is however important to recognize that a number of allogeneic HSCT recipients without clinical diagnosis of GVHD may have functional hyposplenism and are at risk for severe, systemic infection due to encapsulated bacteria

'Indwelling prosthetic devices including intravascular access catheters; surgical drains; implanted prosthesis such as heart valves, joints, biliary, bronchial, urinary tract stents; and other various implantable surgical devices promote infections due to CoNS and Candida spp. that commonly colonizes the skin and genitourinary and orointestinal tracts

${ }^{\mathrm{f}}$ Listeria bacteremia and meningitis are rare complications in patients receiving TMP-SMX prophylaxis for PCP. The incidence of bacterial meningitis is 30-fold higher in HSCT recipients compared with persons without HSCT. As expected, patients undergoing allograft stem cell transplant are at a significant higher risk compared with those undergoing autologous HSCT (70 vs. 16 per 100000 patients per year). In HSCT recipients Streptococcus pneumoniae is the most common pathogen associated with bacterial meningitis, Neisseria meningitidis, Streptococcus mitis; listeriosis may be rarely seen

${ }^{g}$ Increasing frequency of multidrug-resistant strains to fluorinated quinolones and regional high prevalence of extended-spectrum beta-lactamases producing GNB including carbapenem-resistant Enterobacteriaceae has seriously curtailed treatment options for such infections. Enterobacteriaceae include Salmonella spp., Escherichia coli, Yersinia pestis, Klebsiella spp., Shigella, Proteus, Enterobacter, Serratia, and Citrobacter

${ }^{\mathrm{h}} \mathrm{CNS}$ nocardiosis is difficult to distinguish from brain toxoplasmosis, tuberculosis, aspergillosis and other neurotropic clear (hyaline) and black mold infections, and CNS lymphoma

${ }^{i}$ Nonfermentative gram-negatives include Pseudomonas aeruginosa, Burkholderia cepacia, Stenotrophomonas maltophilia, Acinetobacter baumannii, other Acinetobacter spp., Alcaligenes and Achromobacter spp., and emerging cases of Sphingomonas paucimobilis. Inherent or acquired drug resistance is a major concern in selection of effective empiric therapy for pathogens in this group, which may either lack the drug target site or produce extended-spectrum hydrolyzing enzymes aginst a variety of commonly used antimicrobials; these bacteria may also exhibit phenotypes with reduced expression of outer membrane porins and/or heightened expression of efflux pumps among other mechanisms for antimicrobial drug resistance

${ }^{j}$ Orointestinal mucositis increases the risk of CDAD and so does exposure to broad-spectrum antimicrobials and possibly antineoplastic chemotherapy-induced alteration in hosts' intestinal protective anaerobic microbiota 
Table 1.2 (continued)

${ }^{k}$ It now considered standard of care to perform interferon-gamma release assays for diagnosis of latent tuberculosis infection; treatment with isoniazid is considered gold standard and should be administered for a minimum of 6 months prior to the transplantation procedure, with the aim to prevent active tuberculosis infection during the post-transplant period. Such infections tend to be more serious and, due to potential drug toxicity and drug-drug interaction, often difficult to treat after allograft transplantation

${ }^{1} M$. kansasii leads to clinical disease indistinguishable from M. tuberculosis infection; risk for infection relapse, drug resistance, and infection recalcitrance are reason for longer duration of therapy

mIn a recent study from South Korea, in 7342 SOT and 1266 HSCT recipients, 22 patients developed NTM after a median 2 years following transplantation. Mycobacterium avium-intracellulare complex was the most common pathogen isolated; nodular bronchiectasis ( 80\%) was common presentation. A near 70\% response to antimicrobial therapy in this group was encouraging. However, disseminated NTM including MAC disease in severely immunosuppressed patients following high-risk allogeneic HSCT may occasionally present as salvage therapy-refractroy recalcitrant bacteremia with high fatality

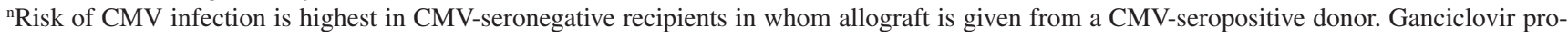
phylaxis effectively prevents CMV disease in high-risk patients during the first 100 days after allogeneic HSCT

${ }^{\circ}$ Late CMV disease is associated with high mortality rate nearing $45 \%$ and seen 170 median days after HSCT. It is important to recognize that close to $40 \%$ of patients that respond to the initial episode of late posttransplant CMV infection will develop a second CMV episode within a median of 11-12 weeks. Three months after HSCT, patients with positive CMV-pp65 antigenemia; post-engraftment severe lymphopenia of less than 100 lymphocytes $/ \mathrm{mm}^{3}$, especially those with helper T-cell lymphocytopenia of less than 50 cells $/ \mathrm{mm}^{3}$; presence of GVHD; and those with undetectable CMV-specific T-cell responses are at higher risk for late CMV end-organ disease. Furthermore, after 100 days following transplantation, presence of CMV viremia or pp65 antigenemia and severe lymphopenia endorsed by less than 300 lymphocytes $/ \mathrm{mm}^{3}$ is considered strong predictors for late CMV disease and death

${ }^{\mathrm{P}}$ Most frequently detected viruses in symptomatic HSCT or SOT recipients with URTI are picornaviruses ( 40\%), such as rhinovirus and enterovirus, whereas coronavirus and influenza are isolated in nearly $20 \%$ of such patients, each. Influenza URTIs similar to RSV and unlike parainfluenza virus infections have the potential for progression to the lower respiratory tract. Viral pneumonitis is a serious complication in patients following allogeneic stem cell transplantation. It is important to recognize that hosts' immune response to influenza infection garners a high IFNgamma state resulting in a transient increased susceptibility for secondary bacterial infections like pneumococcus, S. aureus, and Pseudomonas spp. The resulting superimposed bacterial pneumonia may precipitate life-threatening sepsis and respiratory failure. Furthermore, RTVIs are recognized as fostering enhanced susceptibility for invasive fungal lung disease during early and late transplant periods

${ }^{\mathrm{q}}$ Serologic evaluation of the donor and recipient for latent CMV infection is the cornerstone during pretransplant assessment. Dissonance between $\mathrm{D}+$ and R-CMV serology is the most important complicating factors during early and late posttransplant period. Antiviral prophylaxis, preemptive and empiric therapy approaches are based on CMV serologic disparities

${ }^{\mathrm{r}}$ It is standard to provide prophylaxis for HSV and VZV during preparatory conditioning regimen and continue during the early post-HSCT period. Prophylaxis may have to be extended in patients with acute GVHD, cancer recurrence, patients undergoing high-risk transplantation procedure, and those with primary or secondary allograft compromise

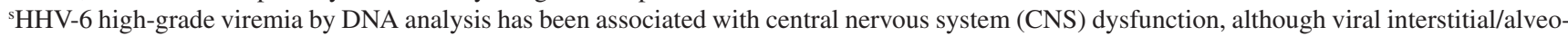
lar pneumonitis is not an uncommon disease attributed to HHV6 infection following allogeneic HSCT. HHV6 may also present as limbic encephalitis with subcortical temporal lobe seizure activity presenting as memory loss and insomnia. Febrile partial or complete myelosuppression and/or skin rash should alert the physicians regarding HHV6 as a potential treatable cause of secondary stem cell allograft loss. Viral gastroduodenitis, colitis, and pericarditis are other clinical manifestations attributed to HHV6 infection in this vulnerable population. An association with post-HSCT HHV6 viremia with delayed monocyte and platelet engraftment, increased platelet transfusion requirements, risk for high-grade GVHD, and allcause mortality needs further evaluation

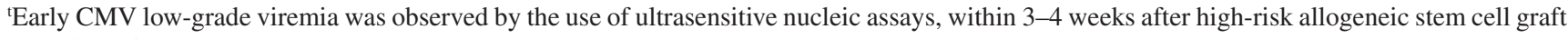
transplantation

"The incidence of adenovirus disease ranges from 3\% to as high as 47\% in high-risk pediatric allogeneic HSCT recipients. Patients undergoing T-cell-depleted stem cell grafts and those with acute graft-versus-host disease are also at increased risk for severe life-threatening adenovirus disseminated disease, which is a well-recognized complication in patients with persistent peripheral blood lymphocyte counts of $<300$ cells $/ \mathrm{mm}^{3}$. Infection involves respiratory (viral pneumonitis), gastrointestinal (colitis, including hemorrhagic colitis) tracts, and hepatitis;patients may present with posttransplant hemorrhagic cystitis. Adenovirus dissemination represents severity of underlying immune defect and is seen in 10-20\% of patients with end-organ viral disease, except in patients with adenovirus cystitis, where disseminated adenoviral disease is seldom observed ${ }^{v}$ Long-term (>30 days) viral shedding is not uncommon in patients following allogeneic HSCT; RSV is notable RTVI in this regard. The 80 days of median duration of viral shedding may extend to just under a year in some allogeneic transplant recipients. This potential for pronged viral shedding warrants heightened awareness and strict adherence to appropriate precautions to prevent nosocomial RSV transmission to other vulnerable hospitalized patients. In the pediatric HSCT recipients, RSV infection within 60 days after transplant, patients given systemic corticosteroids within a week prior to the onset of RSV infection and the need for assisted mechanical ventilation were significant predictors for subsequent complications and death

wThe BK virus was first isolated in 1971; after primary childhood infection, persistent BKV infection occurs within renal tubular cells and the urothelium. Viral reactivation in the recipients of kidney and allogeneic HSCT usually presents as allograft nephropathy and hemorrhagic cystitis, respectively. Presently, reduction in drug-induced immune suppression, when possible, and supportive care are the only viable treatment option; direct antiviral drug against BKV remains elusive

${ }^{x}$ EBV influence over B-cell malignant clones may act through different mechanisms of transcriptional regulation and possibly variance in genetic mechanisms that eventually determined viral latency during early EBV infection and EBV-host interaction

y The incidence of hMPV infection was similar to the incidence of RSV or parainfluenza virus UTRIs in patients undergoing HSCT. hMPV infections are notable for low risk of progression to the LRT. Serious systemic hMPV disease including viral encephalitis has been reported. Overall, these infections are well-tolerated, albeit hMPV pneumonitis in severely immunosuppressed stem cell allograft recipients may result in serious life-threatening lung disease

(continued) 
Table 1.2 (continued)

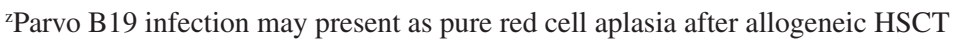

${ }^{a} \mathrm{hCoV}$ similar to hMPV is a common RTV. Serotypes associated with disease in transplant population include hCoV-OC43 followed by NL63, HKU1; 229E is less common. Unlike hMPV, these infections have a higher likelihood for progressing to the LRT, which often presents as subclinical, mild to moderate viral illness. In an observation among HSCT recipients, hCoV infection resulted in a notable number ( 20\%) of hospitalizations. In concert with hMPV infection, despite presence of severe immune suppression, hCoV-related confirmed deaths in allogeneic HSCT recipients remain less than 5\%. Approximately one-third of transplant patients with hCoV infection may have infection due to other RTVs such as human bocavirus $(\mathrm{HBoV})$. HBoV is an uncommon RTV in transplant patients and often (> 80\%) seen with other RTVs. HBoV rarely causes LRTI; most infections are well-tolerated despite, transplant-related severe immune suppression

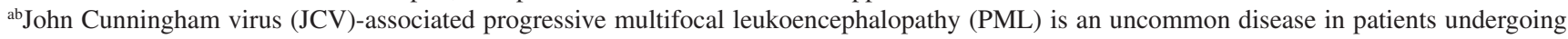
allogeneic HSCT. In a report from Israel, 20 of 40 patients (24\%) with JCV reactivation had persistent viremia after receiving myeloablative and nonmyeloablative pretransplant conditioning. PML was diagnosed in two patients with persistent JCV viremia, 96 and 127 days after HSCT. Advanced age was a significant predictor of JCV reactivation; 70\% of these allogeneic HSCT recipients with persistent viral reactivation had died. Identifying high-risk patients with persistent JCV reactivation, especially those with incremental levels of viremia, may benefit from reduced drug-induced immune suppression for prevention of JCV leukoencephalopathy. PML continues to remain a devastating, albeit rare posttransplant infectious complication. Artesunate, an antimalarial drug that showed potent ex vivo activity against HHV-6, however, clinical response to artesunate in HSCT recipients with JCV-PML, has not been encouraging

${ }^{\text {ac }}$ Candidemia is seen in patients with severe pre-engraftment neutropenia (absolute neutrophil count $<500$ cell/microliter) that extends longer than 5 days. The increase in non-albicans Candida spp. is mainly due to C. glabrata, although patients following HSCT are also at risk for $C$. krusei infection. Emergence of echinocandin resistance among clinical C. glabrata isolates is concerning. For patients with $C$. parapsilosis infection, it is recommended to use antifungal drugs other than echinocandin class. The emergence of MDR Candida auris infections in transplant population makes selection of empiric anti-yeast therapy more challenging

${ }^{\text {ad }}$ Genetic susceptibility for IA include mutations in Dectin-1 and DC-SIGN among other well recognized risk factors such as high-risk allogeneic HSCT, CMV and respiratory virus infection, and positive Aspergillus PCR. It was recently noted that presence of three of the aforementioned factors generated a $57 \%$ probability for developing IA. In patients with no risk factors, the probability of IA was $2 \%$, compared to $~ 80 \%$ in patients with four or more such risk factors

${ }^{a} \mathrm{CMV}$ reactivation after stem cell allograft transplantation increases the risk for IFD during the late transplant period. Unlike the risk factors for early IFD such as AML (HR 3), HLA antigen-mismatched donor graft (HR 3.4); HSCT recipients with lymphoma (HR 8.5), CMV reactivation (HR 5.5), and severe neutropenia (HR 3.5) are considered prominent risk factors for late-onset IFD. Patients with pretransplant IgG responses against Aspergillus proteins indicating significant fungal colonization or ongoing subclinical Aspergillus infections before preparatory conditioning regimen has commenced needs further clinical validation. Evaluation of 5589 HSCT recipients at a comprehensive cancer center between 1985 and 1999 showed increased incidence of IA after 1992 and remained high during that decade. The authors also reported increasing frequency of non-Aspergillus molds such as Fusarium spp. and mucormycosis in the late 1990s. These non-Aspergillus molds were prominent in patients undergoing multiple transplants. Most cases of mucormycosis were seen during the late transplant period, especially in patients with chronic GVHD. In patients undergoing nonmyeloablative HSCT, presence of severe acute GVHD, chronic extensive GVHD, and CMV infection are prominent risk factors for IFD

${ }^{a f}$ Invasive aspergillosis is a complication seen in patients with delayed ( $>2$ weeks) recovery of peripheral blood granulocyte count. Patients receiving high-dose systemic corticosteroids are also at an increased risk. Aspergillus fumigatus remains the most prevalent mold to cause invasive human disease, including in patients undergoing HSCT. Infections caused by Scedosporium and Fusarium spp. are occasionally seen in hematopoietic stem cell allograft recipients and commonly present during the period(s) of severe and prolonged neutropenia

${ }^{\text {ag }}$ Routine blood cultures have low sensitivity for diagnosis of fungemia. Carbohydrate biomarker $(1,3)-\beta$-d-glucan has emerged as a useful laboratory test for the diagnosis of invasive yeast and mold disease. Furthermore, it may be used to monitor response to systemic antifungal therapy and infection relapse

ahPost-HSCT recovery of antigen-specific T lymphocyte-mediated immune response against CMV and Candida albicans is regarded as critical during the early and the late transplant period. Most patients develop antigen-specific T-cell response early in the transplant period which is derived from clones of both donor and recipient stem cell origin. Reconstitution of immune response via antigen-specific T lymphocytes of recipient origin is weakened in patients with GVHD. Incidence of IC during the 1st year after nonmyeloablative (5\%) and myeloablative transplant conditioning is lower than that for IA (14\%). Echinocandin nonsusceptible Candida spp. infection has been recently recognized as an emerging challenge in providing care for these highly vulnerable patients

${ }^{a} \mathrm{PCP}$ is a serious $\mathrm{OI}$ in transplant patients with severe cellular immune defect(s). Routine anti-PCP prophylaxis breakthrough infections are rare; although in patients receiving aerosolized pentamidine, atypical upper lung PCP may occasionally occur

ajInvasive zygomycosis or mucormycosis may occur disproportionally more frequently in patients on voriconazole prophylaxis and those with sinuorbital invasive mold disease. In transplant patients, the overall prevalence is less than $8 \%$ among all invasive fungal infections

${ }^{a k}$ Nearly half of the patients with disseminated fusariosis have evidence of fungemia, and close to $80 \%$ may exhibit multiple (>10-15) papular skin lesions with a necrotic center that is indistinguishable from ecthyma gangrenosum due to Staphylococcus aureus or disseminated Pseudomonas spp. infection

alDematiaceous or melanin pigmented molds are associated with chronic localized infections and prevalent in certain geographic regions. In transplant patients, disseminated infections may occur; neurotropism is an important feature of these infections, and treatment with older antifungal drugs such as amphotericin B and early generation triazole-based compounds was associated with high rates of treatment failure

${ }^{a m}$ The cumulative incidence of CNS infection following HSCT is <1\% within first 30 days, $2 \%$ within 3 months, and $5 \%$ after 5 years following transplantation. Significantly high risk of CNS infection 5 years after CBT (8\%) vs. matched related HSCT (2\%) is important to note for the purpose of risk stratification. CNS fungal (35\%) and viral (32\%) infections are prominent, whereas toxoplasmosis and bacterial infection are seen in just over $10 \%$ of the patients. Aspergillosis is common (67\%) followed by Cryptococcus neoformans (17\%). CNS infection in transplant population is associated with high mortality (59\%), and low (20\%) 5-year overall survival 
Table 1.2 (continued)

an Donor-derived toxoplasmosis has been reported along with cases of brucellosis in the endemic regions, along with West Nile virus infection, rabies, Chagas disease, and rare cases of lymphocytic choriomeningitis virus infection

${ }^{a}$ Strongyloides stercoralis (pinworm or threadworms and Enterobius vermiculari) in the underdeveloped countries where fecal contamination of soil and water is common; evaluation of allogeneic transplant candidates requires serologic evaluation for exposure and if present, appropriate treatment should be completed for intestinal subclinical parasitic infestation prior to the trasnplantation procedure

apIn patients with extensive T-cell immune defects, Strongyloides stercoralis may cause accelerated autoinfection. Hyperinfection pulmonary syndrome in such patients is almost always fatal. Screening serology tests for the presence of strongyloidiasis by enzyme-linked immunosorbent assay after allogeneic HSCT may be falsely negative; and stool ova and parasite examination, in the absence of accelerated autoinfection during the pretransplant, is also riddled with low sensitivity

${ }^{a q}$ American trypanosomiasis caused by Trypanosoma cruzi needs to be assessed in patients planned to undergo allograft transplant procedure from endemic regions

${ }^{a r}$ Leishmania is transmitted by the bite of certain species of sand flies and presents as cutaneous (common) and visceral (uncommon and severe) disease; pretransplant evaluation should include serologic testing for prior exposure to these parasites in appropriate patients with high risk for prior exposure

Abbreviations: $G V H D$ graft-versus-host disease, $H S V$ herpes simplex virus 1 and 2, $C M V$ cytomegalovirus, $V Z V$ varicella zoster virus, $H H V 6$ human herpesvirus 6, EBV Epstein-Barr virus, CoNS coagulase-negative Staphylococcus, CDAD Clostridium difficile-associated diarrhea, GPB gram-positive bacteria, GNB gram-negative bacteria, $H S C T$ hematopoietic stem cell transplantation, $R S V$ respiratory syncytial virus, $h M P V$ human metapneumovirus, $h \mathrm{CoV}$ human coronavirus hypervirulent subtypes NL63 and HKU1, PML progressive multifocal leukoencephalopathy, EBV$P T L D$ Epstein-Barr virus-associated B-cell lymphoproliferative disorder, $H R$ hazard ratio, IFD invasive fungal disease, IA invasive aspergillosis, $I C$ invasive candidiasis, $S O T$ solid organ transplant, $U R T I$ upper respiratory tract infection, $L R T I$ lower respiratory tract infections, $R T V$ respiratory tract virus, RTVIs respiratory tract viral infections, $h C o V$ human coronavirus

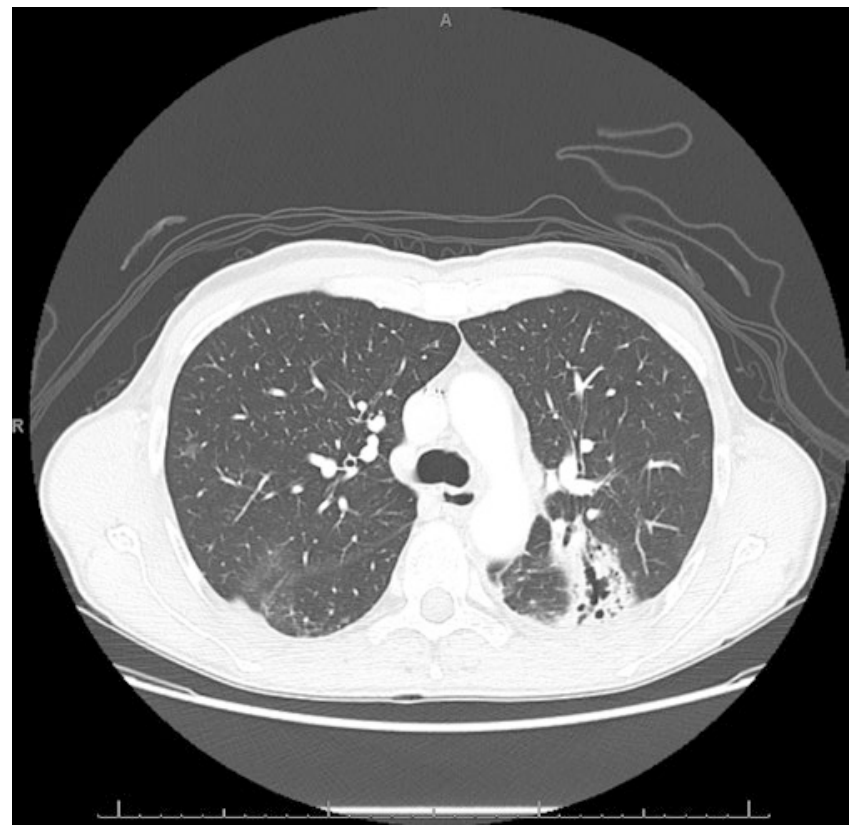

Fig. 1.1 CT scan of lungs without intravenous contrast showing necrotizing left lung Pseudomonas infection in a patient following HSCT. The differential for this thick-walled irregular cavitary lesion is broad and includes other bacterial infection such as Klebsiella spp., Stenotrophomonas maltophilia, Staphylococcus aureus, Streptococcus pneumoniae, Escherichia coli, Nocardia spp.; Mycobacterium tuberculosis and nontuberculous mycobacterial infections. Cavitary rapidly growing cancers may have similar presentation, whereas viral infections including cytomegalovirus and adenovirus seldom present with such features. Other than suppurative necrosis of the lung, ischemic necrosis, i.e. pulmonary infarction, should also be considered. Tissue invasive mold lung disease may also have comparable radiographic presentation

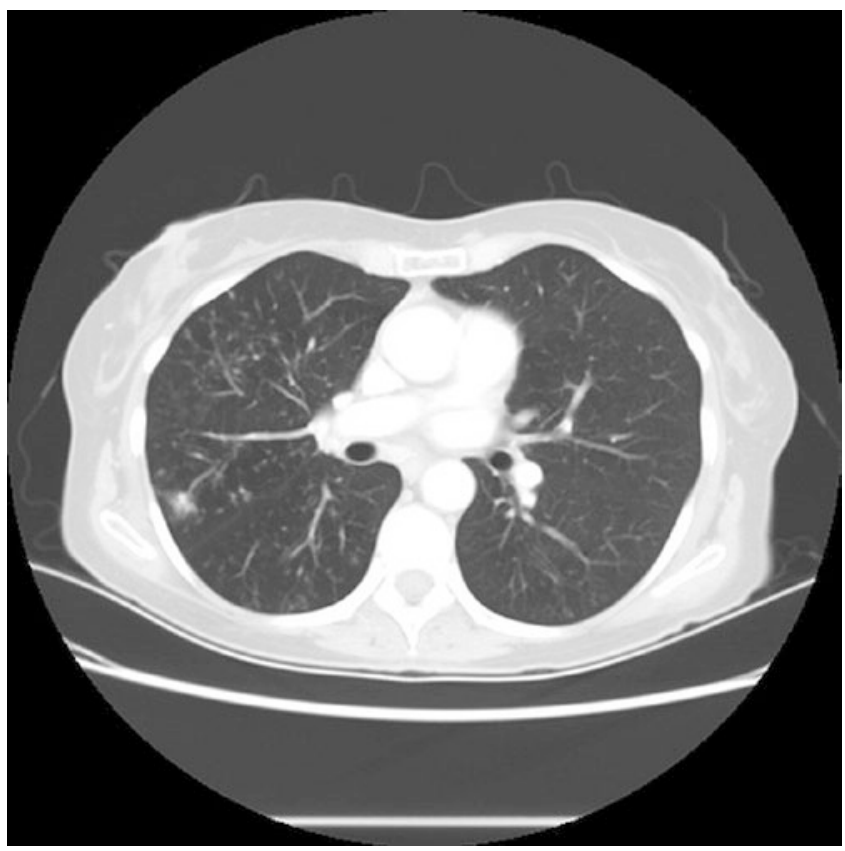

Fig. 1.2 CT scan of lungs without intravenous contrast showing treein-bud appearance due to pulmonary Mycobacterium avium complex disease mostly involving the right lung demonstrating multiple areas of centrilobular nodules with a linear branching pattern. Endobronchial tuberculosis may present with such a radiographic finding, wherein patients with acutely developed tree-in-bud infiltrates bacterial or viral (CMV) etiology may also be entertained. It is important to note that bronchiectasis is the prominent radiographic presentation of Mycobacterium avium complex infection in patients undergoing transplantation. Rarely carcinomatous endarteritis due to breast or gastric cancer; bronchovascular interstitial infiltration due to lymphoma, leukemia, and sarcoidosis may have similar presentation. Scedosporium lung disease and pulmonary fusariosis may occassionally have nodular peribrochovascular distribution 


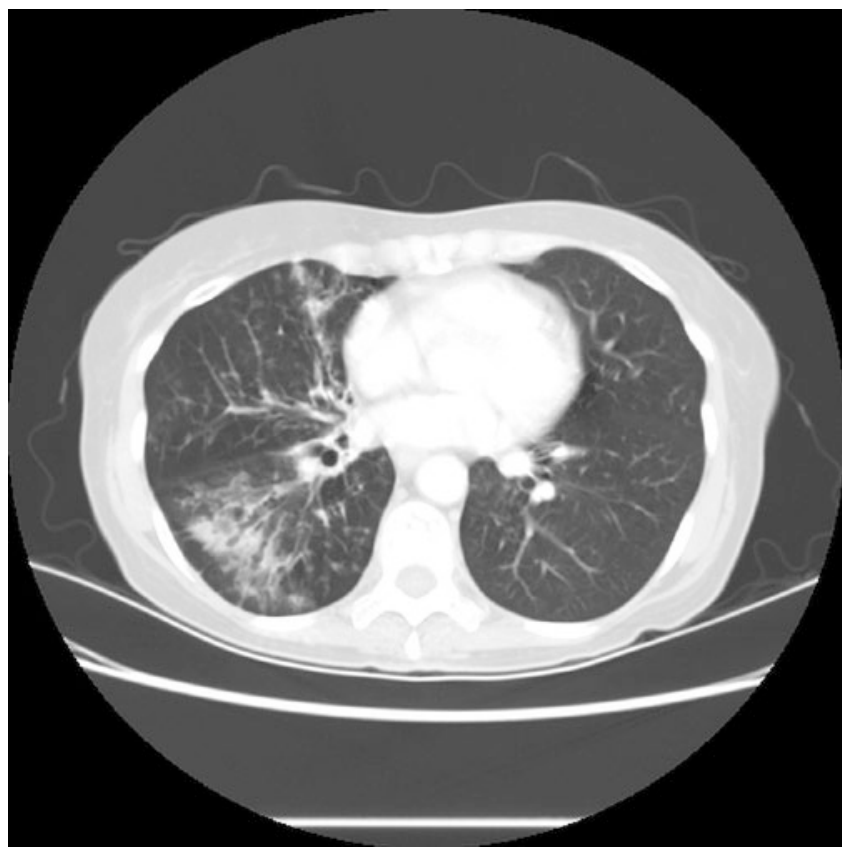

Fig. 1.3 CT scan of lungs without intravenous contrast showing right lung Mycobacterium kansasii pneumonia with peribronchial thickening that could be mistaken for CMV pneumonitis and Mycobacterium tuberculosis, among other lung infections in a patients following allogeneic HSCT

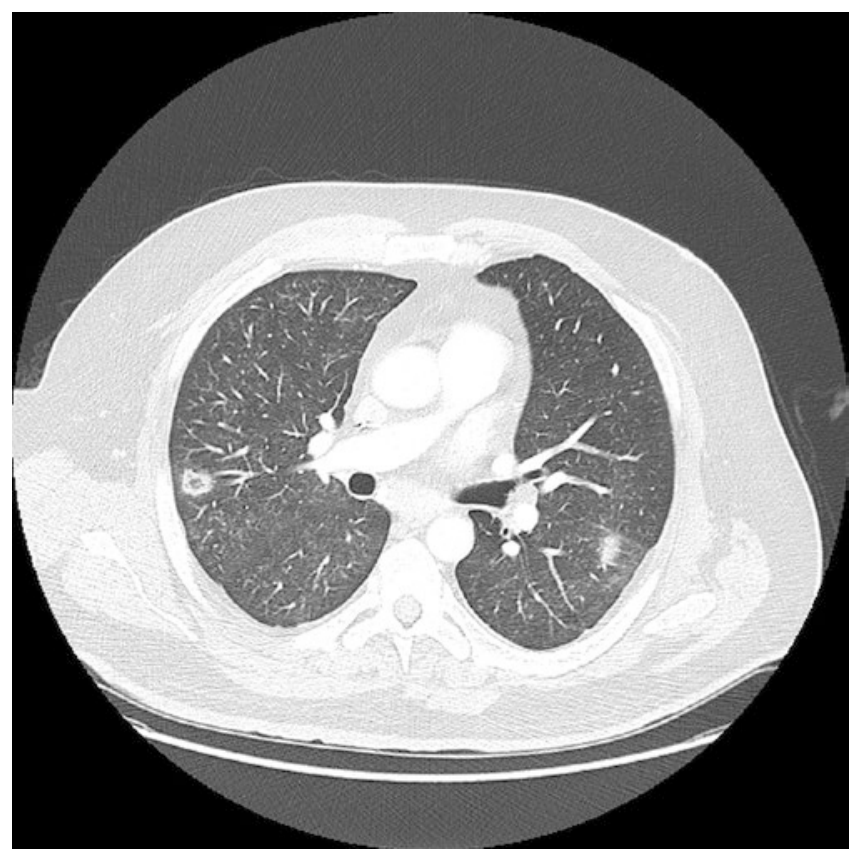

Fig. 1.4 CT scan of lungs without intravenous contrast showing bilateral nodular zygomycosis in a patient following allogeneic HSCT while receiving voriconazole prophylaxis. The right lung nodule with a central cavity cannot be radiographically excluded from other causes of nodular pneumonia such as invasive pulmonary aspergillosis, Fusarium spp., and other mold lung disease. Among bacteria, Nocardia spp. is a concern in allograft transplant recipients with such radiographic presentation. Primary lung lymphoma may have similar presentation. Rarely, patients with relapse acute leukemia in the post HSCT period may present with atypical pulmonary infiltrates

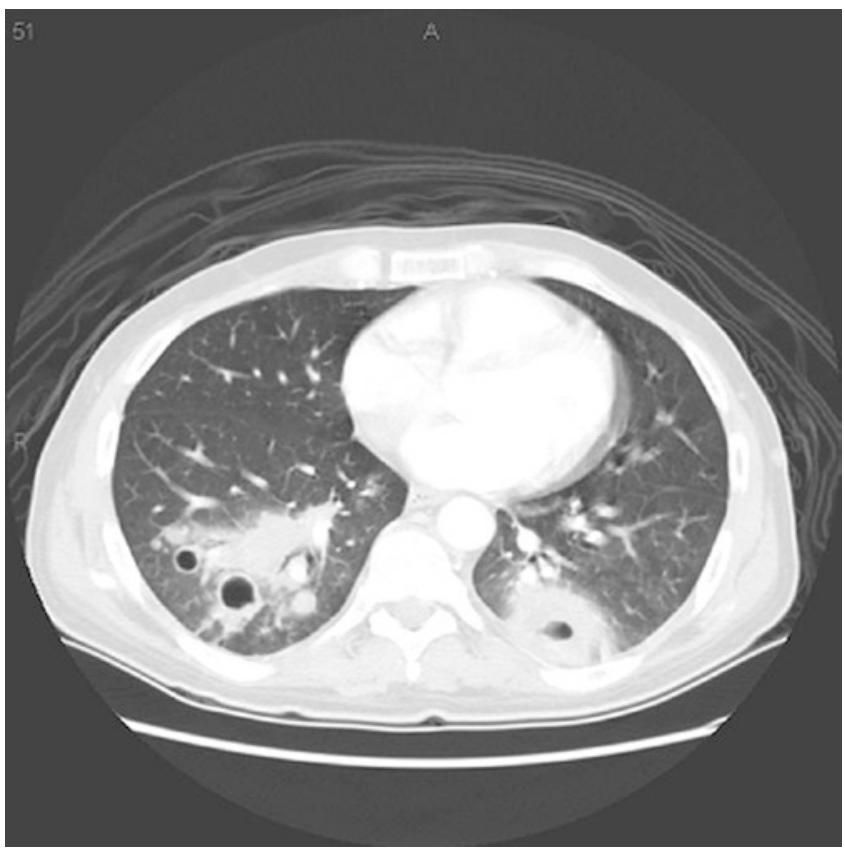

Fig. 1.5 CT scan of lungs without intravenous contrast showing cavitary pneumonia with dense consolidation involving both lower lobes in a patient with GVHD, who developed infection due to dematiaceous mold following allogeneic HSCT. In the differential diagnosis, necrotizing bacterial, clear (hyaline) and black (melanin pigmented) mold infections should also be considered along with multifocal pulmonary nocardiosis

at an additional risk for infections that are often seen in asplenic patients or those with functional hyposplenism. Patients with chronic GVHD are not only at an increased risk for systemic fungal disease like invasive aspergillosis or herpes virus reactivation herald by CMV viremia; additionally, encapsulated bacteria such as outlined in Table 1.1 may also be included in the risk profile during evaluation of such patients.

Patients receiving treatment for acute GVHD after allogeneic HSCT have heightened risk for invasive aspergillosis and infections due to other filamentous molds. Unlike the first risk period for invasive mold disease in allogeneic stem cell recipients, which coincides with the period of preengraftment severe neutropenia, patients with acute and chronic GVHD are seldom neutropenic.

Table 1.3 illustrates the salient features of infection risk and their association with the type of stem cell graft, pretransplant conditioning preparatory regimens, and drugs commonly used in the prevention of GVHD. Cord blood stem cells are regarded as a major breakthrough for source that yields a steady supply of hematopoietic stem cells, especially among patients with difficult to find, immunologically (HLA-matched) compatible hematopoietic stem cell graft [18]. Cord blood stem cells have a limited number of nucleated cells that are adequate for children. In adults 


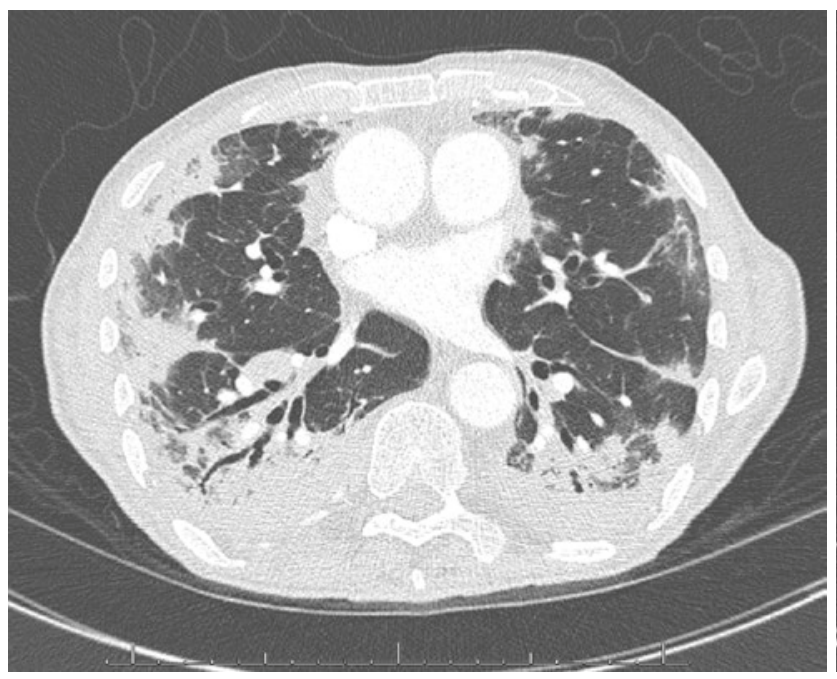

Fig. 1.6 CT scan of lungs without intravenous contrast showing cryptogenic organising pneumonia in a patient following allogeneic HSCT

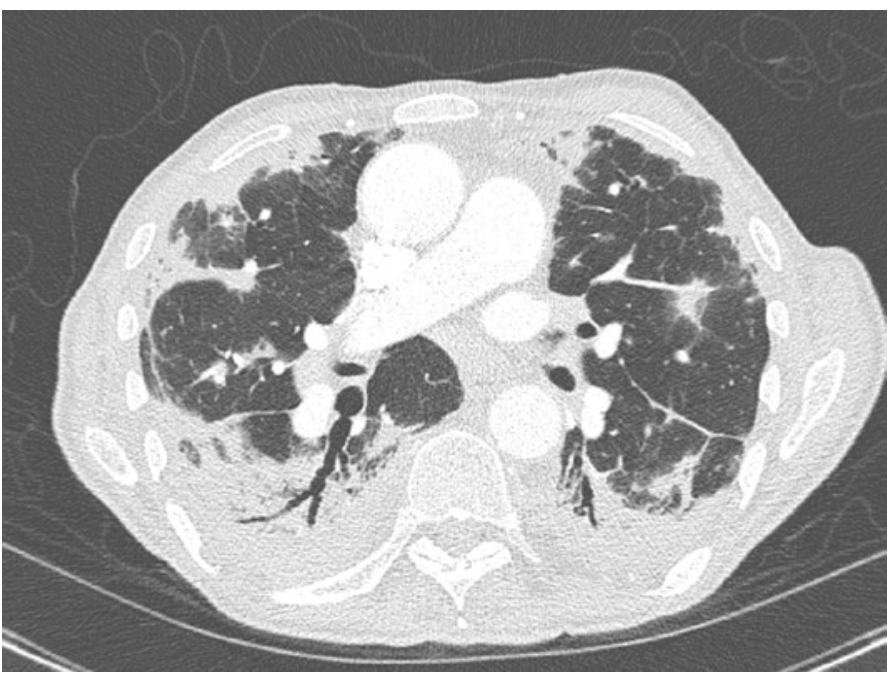

that may be mistaken for fibrosing subacute infection due to endemic mycosis among other causes of subacute lung infection due to larger body surface area, transplantation with less than optimum number of stem cells complicate posttransplant period with issues such as inadequate and delayed neutrophil engraftment and peripheral blood cell count recovery, precarious graft stability, and, similar to recipients of T-cell-depleted grafts, a higher risk for infections associated with severe and prolonged neutropenia or those observed during GVHD (Tables 1.1 and 1.2). Various strategies are being explored to assuage this limitation including transplantation with cord blood grafts from more than one donor and ex vivo expansion of a single donor cord blood graft to increase the yield of nucleated cells [21]. In a review of 100 cord blood transplants at a comprehensive cancer center in Houston, Texas, the infection incidence rate ratio, which was total infection episodes per days at risk (survival after $\mathrm{CBT}) \times 100$, was 2.4 times higher in adult patients compared with children [22]. It was important to note that risk of infection was even greater (three times higher) in adults with neutropenia and was 1.9 times higher in patients with GVHD when compared with children undergoing CBT procedure [22].

It is considered essential to create a comprehensive infection assessment strategy that takes into account and recognizes the local issues at a particular transplant unit and its unique patient population. Such an approach requires cognizance of existing influences that may promote risk for infection including local and regional infection trends, patterns in pathogen prevalence and drug susceptibility profiles. Continued vigilance regarding emergent pathogens and everchanging infection risk profile with advances in transplant procedures and drug-induced immune suppression are of paramount importance in providing care for the highly vulnerable transplant population.

A variety of noninfectious conditions may clinically and radiographically emulate an infectious process. Among these noninfectious maladies, those involving the skin and the lungs are the great imitators; when present, they are difficult to clinically distinguish from infections such as cellulitis or pneumonia. Two chapters in this volume are dedicated to provide an in-depth discussion on these topics.

An approach for establishing correct diagnosis for opportunistic infections is based on the maxim "when uncertain, obtain a tissue sample." A diligent adjudication is the central tenet in establishing accurate diagnosis for the immunologically vulnerable patients, in whom proclivity for atypical disease presentation further complicates ascertaining correct and timely diagnosis. Inaccurate diagnosis under the old dispensation of serologic and culture-based system may lead to inappropriate and ineffective treatment, worsening patients' morbidity, risk for further complications, and death. Therefore, focused yet comprehensive differential diagnoses, which encompasses etiology of infections and noninfectious causes that may mimic an infectious process including but not limited to drug toxicity; de novo malignancies or post transplant cancer recurrence; typical or atypical presentation of lymphoproliferative disorders; immune-inflammatory diseases like GVHD; and tissue infiltrative processes such as solid allograft rejection among others may greatly improve the guidance for an optimized management approach in patients undergoing lifesaving, stem cell and solid organ allograft transplantation. 
Table 1.3 Relationship between infection risk and HSCT variables

\begin{tabular}{|c|c|c|}
\hline $\begin{array}{l}\text { Stem cell source, } \\
\text { preparatory } \\
\text { conditioning regimens, } \\
\text { and GVHD prophylaxis }\end{array}$ & Immune defects & Infections \\
\hline \multirow[t]{6}{*}{$\begin{array}{l}\text { Allogeneic vs. } \\
\text { autologous graft }\end{array}$} & $\begin{array}{l}\text { Allograft recipient exhibits gradual recovery of cellular and } \\
\text { adaptive immune function }\end{array}$ & $\begin{array}{l}\text { Pre-engraftment neutropenia, if longer } \\
\text { than } 7-14 \text { days, increases the risk for invasive } \\
\text { candidiasis and IMD }\end{array}$ \\
\hline & $\begin{array}{l}\text { Innate immune function aided by cellular and acellular } \\
\text { antimicrobial defense is to recover early after transplantation, } \\
\text { especially in patients undergoing conventional autologous and } \\
\text { nonmyeloablative HSCT. It is heralded by granulocyte } \\
\text { engraftment and posttransplant resolution of neutropenia }\end{array}$ & $\begin{array}{l}\text { IFD heightened risk coincides with the peak } \\
\text { incidence of acute and chronic GVHD }\end{array}$ \\
\hline & $\begin{array}{l}\text { Complements and antimicrobial peptides reconstitute early after } \\
\text { transplantation }\end{array}$ & $\begin{array}{l}\text { Severe respiratory viral infections are also } \\
\text { problematic in patients given systemic } \\
\text { corticosteroids and immunosuppressive therapy } \\
\text { for GVHD }\end{array}$ \\
\hline & $\begin{array}{l}\text { Patients with persistent severe thrombocytopenia that may follow } \\
\text { in high-risk allogeneic stem cell recipients may continue to exhibit } \\
\text { reduced host defense due to suboptimum thrombin-releasable } \\
\text { antimicrobial peptides from platelets including platelet factor } 4 \text {, } \\
\text { RANTES, connective tissue-activating peptide } 3 \text {, platelet basic } \\
\text { protein, thymosin } \beta-4 \text {, fibrinopeptide B, and fibrinopeptide A. The } \\
\text { impact of depleted platelet-assisted immune defense and } \\
\text { potentially higher susceptibility for infection in HSCT recipients } \\
\text { with severe thrombocytopenia is not certain }\end{array}$ & \multirow[t]{3}{*}{$\begin{array}{l}\text { CMV, less commonly HHV6, and disseminated } \\
\text { adenovirus are encountered in patients with } \\
\text { profound defects in anti-CMV and other antiviral } \\
\text { pathogen-specific, effector cellular immune } \\
\text { response }\end{array}$} \\
\hline & $\begin{array}{l}\text { Myeloid and plasmacytoid dendritic cells are recovered within } \\
60 \text { days after allogeneic HSCT to pretransplant levels, unless } \\
\text { patients develop acute GVHD, in which case this recovery is } \\
\text { significantly delayed. However, it may take a year or longer to } \\
\text { achieve normal functional DC cell population after undergoing } \\
\text { allogeneic stem cell transplantation. Plasmacytoid DCs are } \\
\text { important for regulation and maintenance of immune tolerance } \\
\text { and defense against viruses. The myeloid DCs serve as APCs that } \\
\text { are pivotal in eliciting pathogen-directed cellular adaptive immune } \\
\text { response }\end{array}$ & \\
\hline & $\begin{array}{l}\text { Recovery of NK cells in most patients undergoing allogeneic } \\
\text { HSCT occurs usually } 45 \text { days after transplantation. These innate } \\
\text { immune effector cells can directly lyse virus-infected cells and } \\
\text { provide antineoplastic immune surveillance. NK cells are an } \\
\text { important, readily available, albeit transient source of IFN } \gamma \text { and } \\
\text { GM-CSF. The chemokines such as MIP-1 } \alpha \text {, MIP-1 } \beta \text {, IL- } 8 \text {, and } \\
\text { RANTES play a critical role in adaptive immune modulation. It } \\
\text { was notable that lack of qualitative NK cell recovery in patients } \\
\text { with T-cell-depleted transplant may render them less effective for } \\
\text { prolonged periods }\end{array}$ & \\
\hline
\end{tabular}


Table 1.3 (continued)

\begin{tabular}{l|l}
$\begin{array}{l}\text { Stem cell source, } \\
\text { preparatory } \\
\text { conditioning regimens, } \\
\text { and GVHD prophylaxis }\end{array}$ & Immune defects \\
\hline $\begin{array}{l}\text { Unrelated donor or } \\
\text { mismatched stem cell } \\
\text { graft }\end{array}$ & $\begin{array}{l}\text { Unrelated donor grafts are more frequently associated with severe } \\
\text { GVH and/or graft rejection compared with sibling donor stem }\end{array}$ \\
\hline
\end{tabular}

Slow reconstitution of adaptive cellular helper and cytotoxic immunity, which is further delayed in patients requiring treatment for acute GVHD

Humoral immune response may not fully recover in patients with chronic GVHD

Bone marrow as the source of stem cells and treatment with high-dose corticosteroids delay recovery of functional T-cellbased immunity for 3 months or longer after transplantation

Peripheral blood stem cell graft vs. bone marrow stem cells
Faster neutrophil engraftment

Blood stem cell grafts have higher lymphocyte subset counts, which, in most part, account for fewer infectious complications during the posttransplant period

Late transplant immune suppression due to chronic GVHD may occur

\section{Infections}

Mismatched and unrelated donor stem cell allograft transplants carry a significant risk for serious life-threatening infections seen in the late (6-18 months) post-transplant period. CMV infection and acute GVHD contribute significantly toward this risk. The late fatal infections include pneumonia, sepsis, central nervous system infection, and disseminated varicella

IA 6 months after transplantation was associated with chronic GVHD and CMV disease

Fusarium spp. IFD is threefold higher in patients undergoing HLA-mismatched vs. HLA-matched HSCT; most cases occur 48 median days after transplantation. The trimodal distribution similar to IA coincides with pre-engraftment neutropenia; 60 days and over 1 year after transplant, corresponding with the incidence of acute and chronic GVHD, respectively

Persistent neutropenia similar to that seen in cases with disseminated Scedosporium spp. infection and other invasive mold disease after allogeneic HSCT was the prominent prognosticator for death in patients with fusariosis

It has also been recognized that subclinical CMV reactivation in patients while on ganciclovir prophylaxis or preemptive therapy appears to be a potent stimulator of T-cell function after transplantation

Other serious infections include EBV-PTLD, disseminated HHV-6, and disseminated adenovirus infections

The rate of severe and proven infections following stem cell engraftment was $\geq$ twofold higher in patients in whom bone marrow SCT was given compared with those undergoing transplantation with PBSC allografts

HLA-matched, related-donor peripheral blood stem cells appear to lend protection against IA during early transplant period compared with those undergoing similar bone marrow stem cell allograft transplants

The greatest benefit of PBSC vs. BMSC has been noted in the risk profile for IFD, whereas for bacterial infections such benefit is intermediate, and it is least for viral infections 
Table 1.3 (continued)

\section{Stem cell source, preparatory conditioning regimens, and GVHD prophylaxis} Cord blood stem cell graft

T-cell-depleted stem cell graft
Immune defects

Slower neutrophil engraftment resulting in prolonged neutropenia in adult CBT recipients continues to be a serious limitation for this stem cell donor source

Adult patients require a higher number of total nucleated cells and CD34+ progenitors than are often present in a cord blood unit, yielding to instability of the allograft even after successful engraftment. To mitigate these limitations, especially in adults, strategies to expand selected subpopulations of stem cell within the cord blood unit and transplantation of multiunit $\mathrm{CB}$ are currently being explored

Slower restitution of T-cell pathogen-specific, cellular immune response as cord blood T-cells are predominantly naïve and exhibit suboptimum T-cell proliferation and IFN-gamma production in response to an insult or exposure to a foreign antigen. This inherent cellular dysfunction in CBS grafts appears to reflect defect(s) in signal transduction pathway(s)

Furthermore, T-cell dysfunction may also arise from prominence of Treg population in CBS with potent suppressor function compared with moderate Treg population in adult donor-derived stem cell grafts

Hypogammaglobulinemia and other B-cell dysfunction may occur in patients with chronic GVHD

Risk of graft rejection and severe acute GVHD have been comparable to that observed following PBSC or BMSC transplants; this is despite high degree of HLA antigen donorrecipient disparity in most adult patients undergoing CBT Graft-versus-leukemia/lymphoma effect in CBT recipients has also been comparable to conventional stem cell graft transplants

\section{Higher risk for graft rejection may be an issue}

Slower reconstitution of cellular and humoral immunity

CD8 cells recover rapidly, whereas helper T-cells and B lymphocyte recovery remain significantly stunted for 1 year or longer after T lymphocyte-depleted stem cell graft transplantation Natural killer cells also make early and sustained recovery after transplantation

Despite T-cell-depleted PBSC grafts having higher numbers of mononuclear cells and granulocyte-macrophage units compared with BM grafts, recovery in B lymphocyte and T-cell subpopulations has not been dissimilar, in either group These patients also exhibit a subnormal level of primed T-cell repertoire. Prominent lymphocyte population in such stem cell grafts is composed of naïve/unprimed T-cells. Primed T lymphocytes including activated helper T-cells that are an important and sustained source of IFN-gamma, a critical cytokine in targeted intracellular neutralization of various pathogens Hypogammaglobulinemia has not been an issue in patients undergoing T-cell-depleted vs. conventional stem cell transplantation
Infections

Cord blood stem cell transplantation increases the risk of early ( $<40$ days) IAs

CBT recipients had a higher incidence of severe bacterial infections within 100 days after transplantation; however, 3 years after CBT, risks of severe bacterial and other infections are comparable to patients undergoing BMT or peripheral blood allogeneic HSCT

CMV infection and/or presence of acute GVHD significantly increases the risk for IA

Most (>90\%) IFD similar to bacterial infections are seen within 100 days after transplantation

Nearly half of the early fungal infections may be noted within the first 30 days after CBT

$\mathrm{CMV}$ and varicella zoster virus infections after 100 days following CBT are mostly seen in patients with chronic GVHD

Patients who recover peripheral blood lymphocyte count following successful CBT engraftment are at a significantly low risk for serious systemic infections

These patients have a higher risk of infections during the prolonged pre-engraftment neutropenia The risk factors for IA noted in allogeneic HSCT recipients include T-cell-depleted or DC34selected stem cell grafts, treatment with systemic corticosteroids, GVHD, presence of severe lymphocytopenia, and neutropenia

CMV infection and end-organ disease; LRTI due to RTVs are now recognized as important predictors for IA and other IFD during postengraftment period 
Table 1.3 (continued)

\begin{tabular}{|c|c|c|}
\hline $\begin{array}{l}\text { Stem cell source, } \\
\text { preparatory } \\
\text { conditioning regimens, } \\
\text { and GVHD prophylaxis }\end{array}$ & Immune defects & Infections \\
\hline \multirow[t]{7}{*}{$\begin{array}{l}\text { Nonmyeloablative stem } \\
\text { cell transplantation }\end{array}$} & $\begin{array}{l}\text { Faster neutrophil engraftment following reduced intensive } \\
\text { preparatory regimen }\end{array}$ & $\begin{array}{l}\text { Patients with chronic lymphocytic leukemia ( } 138 \\
\text { episodes/100 person-years) and recipients of } \\
\text { matched unrelated donor graft ( } 128 \text { episodes/100 } \\
\text { person-years) had higher risk of infection after } \\
\text { NMT }\end{array}$ \\
\hline & $\begin{array}{l}\text { Blood stem cell recipients have higher lymphocyte subset counts } \\
\text { and account for fewer infectious complications during } \\
\text { posttransplant period }\end{array}$ & $\begin{array}{l}\text { Nearly half of the CMV viremia is noted } \\
\text { between } 31 \text { and } 100 \text { days after transplantation. } \\
\text { CMV infection as expected is mostly } \\
\text { encountered after the resolution of neutropenia }\end{array}$ \\
\hline & $\begin{array}{l}\text { Substantially reduced incidence of GVHD, especially severe grade } \\
\text { III-IV acute GVHD }\end{array}$ & $\begin{array}{l}\text { Close to } 80 \% \text { of IFI are late transplant infections } \\
\text { that are diagnosed } 100 \text { days after NMT and } \\
\text { associated with unacceptably high mortality } \\
(\sim 80 \%) \text {. Presence of GVHD and treatment with } \\
\text { systemic corticosteroids significantly increases } \\
\text { the risk for IFD in such patients }\end{array}$ \\
\hline & $\begin{array}{l}\text { Late transplant immune suppression due to chronic GVHD may } \\
\text { occur }\end{array}$ & \\
\hline & $\begin{array}{l}\text { B-cell dysfunction, when present, is often represented as } \\
\text { deficiencies of immunoglobulin subclasses rather than severe } \\
\text { hypogammaglobulinemia }\end{array}$ & $\begin{array}{l}\text { The risk of IA after NMT appears to increase } \\
\text { with time, while well-under } 10 \% \text { within } 1 \text { year } \\
\text { after HSCT, the overall risk increases to around } \\
10 \% \text { at } 2 \text { years and close to } 15 \% 3 \text { years after } \\
\text { transplantation. Patients with GVHD involving } \\
\text { the intestinal tract show a significant risk for IA } \\
\text { after NMT }\end{array}$ \\
\hline & $\begin{array}{l}\text { As in all transplant recipients including those undergoing } \\
\text { autologous SCT, B-cell hyporesponsiveness is clinically } \\
\text { demonstrated as reduced immunogenicity for convention vaccines. } \\
\text { Response to protein conjugate vaccines tends to be superior } \\
\text { compared with response elicited by pure polysaccharide and other } \\
\text { complex sugar immunogens. Superior conjugate vaccine } \\
\text { construct requires restitution of cellular immune response and a } \\
\text { functional antigen presentation process }\end{array}$ & $\begin{array}{l}\text { GVHD treatment with daclizumab further } \\
\text { enhances the risk for IA. Daclizumab is a } \\
\text { humanized monoclonal antibody that binds to } \\
\text { CD25, the alpha subunit of the IL-2 T-cell } \\
\text { receptor resulting in severe iatrogenic drug- } \\
\text { induced cellular immune suppression }\end{array}$ \\
\hline & $\begin{array}{l}\text { Adults with rapid engraftment of NMT become full donor T-cell } \\
\text { chimeras within } 6 \text { months after transplantation. In contrast to } \\
\text { children, quantitative B-cell recovery in adults is usually delayed } \\
\text { until } 1 \text { year after HSCT. It was interesting that immune } \\
\text { reconstitution occurs faster in children undergoing NMT who } \\
\text { exhibit extended duration of mixed hematopoietic chimerism, } \\
\text { whereas in adults, reconstitution is more gradual despite rapid } \\
\text { donor stem cell engraftment and T-cell chimerism }\end{array}$ & \\
\hline
\end{tabular}


Table 1.3 (continued)

\section{Stem cell source, preparatory conditioning regimens, and GVHD prophylaxis} Total body irradiation and chemotherapyinduced mucositis

Antithymocyte globulin

\section{Immune defects}

Radiation exposure and highly active antineoplastic drugs kill rapidly proliferating cancer cells. The rapidly dividing normal orointestinal epithelial cells also sustain unintended damage that may clinically present in patients with severe and potentially life-threatening mucositis

Various strategies including recombinant human keratinocyte growth factor among others are being explored to mitigate this serious debilitating complication commonly seen in the early posttransplant period

Initial phase of chemotherapy-induced stomatotoxicity is infiltration of tissue with inflammatory cells and vascular congestion, followed by epithelial cell damage resulting in ulceration; risk for bacterial and less often yeast invasion resulting in systemic infection. Patients who survive this phase are expected to make full recovery

Divergent cytokine response plays an important role in the risk, severity, and duration of mucositis as does hosts' genetic predisposition

ATG is polyclonal human antilymphocyte globulins that result in multifaceted immunomodulation and are shown to reduce the incidence of solid organ graft rejection and GVHD following allogeneic HSCT

ATG in vivo depletes proinflammatory cytotoxic T-cells in the peripheral blood via complement-dependent cell lysis, and peripheral lymphoid tissue T-cell depletion occurs via cell activation and apoptosis

ATG downregulates expression of the $\alpha$-chain of the IL-2 receptor (CD25), which is expressed on activated T lymphocytes thereby interrupting an important signal for cell proliferation

Modulation of key cell surface molecules such as integrins and intercellular adhesion molecules that facilitate and regulate lymphocyte interactions with the endothelium. Chemotaxis is effected by interference with CXCR4 and stromal cell-derived factor- $1 \alpha$-driven lymphocyte migration

ATG induces apoptosis in B-cell lineages

It promotes and expands functionally immunosuppressive regulatory T-cells

\section{Infections}

Patients with severe mucositis, especially those with mucosal ulcerations, have threefold higher risk for $\alpha$-hemolytic streptococcal bacteremia compared with those without ulcerative mucositis following HSCT. In such patients, presence of oral ulcerations significantly increases the length of hospitalization by nearly 1 week

Similarly, presence of orointestinal mucositis has been associated with the risk for neutropenic enterocolitis or typhlitis and CDAD

The risk of fungemia due to Candida spp. may also be increased in such patients

Patients with intestinal VRE colonization and mucosal disruption heighten the risk for systemic invasion and risk of VRE bloodstream infection Later TBI complication between 12 and 136 months after treatment is mostly noninfectious and includes restrictive lung disease $(\sim 8 \%)$ and altered pulmonary diffusing capacity $(\sim 12 \%)$; pulmonary complications had been statistically higher in patients with GVHD and those who underwent high-dose (15 MV vs. $9 \mathrm{MV}$ ) energy beam radiation therapy. Ocular complications are noted in nearly $30 \%$ of patients on long-term follow-up and include cataract and dry eye syndrome ( $15 \%$ each), whereas keratitis is seldom seen

The incidence of EBV-related complications was twice as high $(\sim 7 \%)$ in patients undergoing non-HLA-matched vs. HLA-matched allograft stem cell transplants. This risk was significantly higher $(>20 \%)$ in patients given antithymocyte globulin versus those in whom this treatment was not given $(<2 \%)$. In HSCT recipient with persistent EBV reactivation, just above $80 \%$ developed EBV-related PTLD suggested targeted surveillance Febrile illness, CMV infection, and hematologic abnormalities are known complications in patients treated with ATG

Abbreviations: $G V H D$ graft-versus-host disease, $C M V$ cytomegalovirus, $D C$ dendritic cells, $N K$ natural killer, $P M L$ JC virus-associated progressive multifocal leukoencephalopathy, PTLD Epstein-Barr virus-associated B-cell lymphoproliferative disorders, IFD invasive fungal disease, $C D A D$ Clostridium difficile-associated diarrhea, $C B T$ cord blood stem cell transplantation, IA invasive aspergillosis, IC invasive candidiasis, Treg regulatory T-cells, HSCT hematopoietic stem cell transplantation, IMD invasive mold disease, HHV6 human herpes virus 6, RANTES regulated on activation, normal T-cell expressed and secreted, $A P C$ antigen-presenting cells, IFN $\gamma$ interferon gamma, NTM nonmyeloablative transplant, NST, $G M-C S F$ granulocyte-macrophage colony-stimulating factor, $C B S$ cord blood stem cells, $B M S C$ bone marrow stem cells, $P B S C$ peripheral blood stem cells, LRTI lower respiratory tract infection, SCT stem cell transplant, HLA human leukocyte antigen 


\section{References}

1. Singh AK, McGuirk JP. Allogeneic stem cell transplantation: a historical and scientific overview. Cancer Res. 2016;76:6445-51.

2. Sass DA, Doyle AM. Liver and kidney transplantation: a half-century historical perspective. Med Clin North Am. 2016;100:435-48.

3. Roche NA, Blondeel PN, Van Lierde KM, Vermeersch HF. Facial transplantation: history and update. Acta Chir Belg. 2015;115:99-103.

4. Garrett GL, Beegun I, D'souza A. Facial transplantation: historical developments and future directions. J Laryngol Otol. 2015;129:206-11.

5. Sá H, Leal R, Rosa MS. Renal transplant immunology in the last 20 years: a revolution towards graft and patient survival improvement. Int Rev Immunol. 2017;36:182-203.

6. Chinen J, Notarangelo LD, Shearer WT. Advances in basic and clinical immunology in 2014. J Allergy Clin Immunol. 2015;135:1132-41.

7. Brent L. Transplantation tolerance - a historical introduction. Immunology. 2016;147:267-8.

8. Boieri M, Shah P, Dressel R, Inngjerdingen M. The role of animal models in the study of hematopoietic stem cell transplantation and GvHD: a historical overview. Front Immunol. 2016;30(7):333.

9. Cichocki F, Verneris MR, Cooley S, Bachanova V, Brunstein CG, Blazar BR, et al. The past, present, and future of NK cells in hematopoietic cell transplantation and adoptive transfer. Curr Top Microbiol Immunol. 2016;395:225-43.

10. Meirelles Júnior RF, Salvalaggio P, Rezende MB, Evangelista AS, Guardia BD, Matielo CE, et al. Liver transplantation: history, outcomes and perspectives. Einstein (Sao Paulo). 2015;13:149-52.

11. Grinyó JM, Cruzado JM. Mycophenolate mofetil and sirolimus combination in renal transplantation. Am $\mathrm{J}$ Transplant. 2006;6:1991-9.

12. Stallone G, Schena A, Infante B, Di Paolo S, Loverre A, Maggio G, et al. Sirolimus for Kaposi's sarcoma in renal-transplant recipients. N Engl J Med. 2005;352:1317-23.

13. Faulkner RD, Craddock C, Byrne JL, Mahendra P, Haynes AP, Prentice $\mathrm{HG}$, et al. BEAM-alemtuzumab reduced-intensity allo- geneic stem cell transplantation for lymphoproliferative diseases: GVHD, toxicity, and survival in 65 patients. Blood. 2004;103:428-34.

14. Hanaway MJ, Woodle ES, Mulgaonkar S, Peddi VR, Kaufman DB, First MR, et al. Alemtuzumab induction in renal transplantation. N Engl J Med. 2011;364:1909-19.

15. Choquet S, Leblond V, Herbrecht R, Socié G, Stoppa AM, Vandenberghe P, et al. Efficacy and safety of rituximab in B-cell post-transplantation lymphoproliferative disorders: results of a prospective multicenter phase 2 study. Blood. 2006;107:3053-7.

16. Safdar A, Armstrong D. Infectious morbidity in critically ill patients with cancer. Crit Care Clin. 2001;17:531-70.

17. Safdar A, Armstrong D. Infections in patients with hematologic neoplasms and hematopoietic stem cell transplantation: neutropenia, humoral, and splenic defects. Clin Infect Dis. 2011;53: 798-806.

18. Weber D, Jenq RR, Peled JU, Taur Y, Hiergeist A, Koestler J, et al. Microbiota disruption induced by early use of broad-spectrum antibiotics is an independent risk factor of outcome after allogeneic stem cell transplantation. Biol Blood Marrow Transplant. 2017;23:845-52.

19. Galloway-Pena JR, Jenq RR, Shelburne SA. Can consideration of the microbiome improve antimicrobial utilization and treatment outcomes in the oncology patient? Clin Cancer Res. 2017;23(13):3263-8.

20. Lee YJ, Arguello EP, Jenq RR, Littmann E, Kim GJ, Miller LC, et al. Protective factors in the intestinal microbiome against clostridium difficile infection in recipients of allogeneic hematopoietic stem cell transplantation. J Infect Dis. 2017;215:1117-23. [Epub ahead of print] PubMed PMID: 28329030.

21. Kiernan J, Damien P, Monaghan M, Shorr R, McIntyre L, Fergusson $\mathrm{D}$, et al. Clinical studies of ex vivo expansion to accelerate engraftment after umbilical cord blood transplantation: a systematic review. Transfus Med Rev. 2017;31:173-82.

22. Safdar A, Rodriguez GH, De Lima MJ, Petropoulos D, Chemaly RF, Worth LL, et al. Infections in 100 cord blood transplantations: spectrum of early and late posttransplant infections in adult and pediatric patients 1996-2005. Medicine (Baltimore). 2007; $86: 324-33$. 